\section{SSCM T \\ Journal of Sustainable Construction \\ Materials and Technologies}

Journal of Sustainable Construction Materials and Technologies

\title{
Design Criteria of Soil Structure Interaction: Marmara Forum Car Park in the Centre of the City
}

\author{
Süleyman Cem Divrik ${ }^{1, *}$, Mehmet Fatih Altan ${ }^{1}$ \\ ${ }^{1}$ Istanbul Aydın University, Halit Aydın Kampüsü No:38, Sefaköy-Küçükçekmece, Istanbul, 34295
}

Manuscript Received July 10, 2018; Accepted July 25, 2018

\begin{abstract}
The design of a three storey steel parking lot under permenant loadings is implemented on the context of the thesis. Suitable sizing of the construction in terms of current regulations is effort.

It is an necessity that making evaluation of geotechnical and engineering of necessary support structure and definition of suitable excavation and support systems in terms of deformation and strength speciailities of the units that can be emerged on excavation phase. In this regard, design is realised on the parallel of remaining on limitation conditions of unit deplacement values within the executing of necessary braced system. The solution of the braced system is done with the support of PLAKXIS. Ground studies report which is scoped to definition of mechanical and dynamical parameters of ground layers which is going to be confronted on excavation phase and the base ground layer are prepared and the design criterias are specified in terms of this report. Loading values are defined on ETABS structural analysis programs with the highlight of these informations. On this context calculation models are constituted.

On the context of this thesis, structural geotechnical interaction is investigated together. Statical and dynamical affects are examined. Structural behaviour in contrast to soil is viewed and the necessities are expressed with detail.
\end{abstract}

\section{Introduction}

In this study, a three-story steel car park was designed under permanent loads. We have been working on sizing the structure according to today's regulations.

Construction There are roads and structures to be affected by foundation excavation within the scope of "IBB Additional Service Building Maintenance and Repair Work" which will be started within the boundaries of Bakırköy district of Istanbul. In order to prevent damage to these structures during excavation during the construction period, excavation support was needed temporarily. Geotechnical engineering evaluation of the necessary support structure should be made and excavation and support systems should be determined in accordance with the strength and deformation characteristics of the units to be encountered during the excavation.

Our steel car park is 3 storeys and the height of the floors is 3.6 meters, 3.2 meters, 3.1 meters. The steel profiles to be used in the construction are based on the steel grade materials S235 and S275. The IPE and pipe profiler are designed with the S235 steel grade in mind. Made profiler, box profiler, UNP profiler and plates are of steel grade S275. The accessory steel shall be made in accordance with TS 708. Steel profiles are designed according to TS-EN 10025-2 regulation.

\footnotetext{
* Corresponding author.

E-mail address: divrikcem@gmail.com (S.C. Divrik)

https://doi.org/10.29187/jscmt.2020.51
} 
The tops of the stairs and the elevator pits were closed at a height of 3.5 meters from the top. The structure is divided into 2 dilatation and designed as 3 models.

Composite flooring system is used in all blocks. A number of advantages have been achieved by using the composite flooring system. There is no need to use mold when using trapezoid sheet. Assembly is easy. There is no need to install the scaffolding. The composite system shortens the construction period. A safe system is established. The steel sheet retains horizontal displacements due to the steel bell support.

\section{Material Characteristics}

The pressure strength is used when the concrete class is determined. Standard test cylinders with an altitude of $300 \mathrm{~mm}$ and a diameter of $150 \mathrm{~mm}$ are formed. These samples are left for 28 days. Finally, the compressive strengths are measured. This figure is also defined in TS-3068. The characteristic compressive value obtained from the cylinder samples was determined to be about $10 \%$ smaller than the characteristic compressive value of the cube samples. Therefore, the characteristic compressive values of the cube samples are used. The characteristic compressive strength, FcK, is tested with validated coefficients. Table 1 gives the strength values and concrete classes of the cube sample with dimensions of $150 \mathrm{~mm}$. All of the reinforced concrete sections in this construction are designed to be concrete class C40. It will be the concrete class $\mathrm{C} 16$ of grobeton which will be applied only to foundation.

Table 1. Concrete Classes and strengths

\begin{tabular}{|c|c|c|c|c|c|c|}
\hline Type & $\begin{array}{l}\text { Concrete } \\
\text { Class }\end{array}$ & $\begin{array}{l}\text { Characteristic } \\
\text { Compressive } \\
\text { Strength fck (MPa) } \\
\end{array}$ & $\begin{array}{l}\text { Calculated } \\
\text { Compressive } \\
\text { Strength fcd (MPa) } \\
\end{array}$ & $\begin{array}{l}\text { Characteristic } \\
\text { Traction Strength fctk } \\
(\mathrm{MPa})\end{array}$ & $\begin{array}{l}\text { Calculation } \\
\text { Strength fctd } \\
(\mathrm{MPa})\end{array}$ & $\begin{array}{l}\text { Elasticity } \\
\text { Module } \\
(\mathrm{MPa}) \\
\end{array}$ \\
\hline 1 & $\mathrm{C} 16$ & 16 & 10,67 & 1,40 & 0,87 & 27000 \\
\hline 2 & $\mathrm{C} 18$ & 18 & 12,00 & 1,50 & 0,90 & 27500 \\
\hline 3 & $\mathrm{C} 20$ & 20 & 13,33 & 1,60 & 1,00 & 28000 \\
\hline 4 & $\mathrm{C} 25$ & 25 & 16,67 & 1,80 & 1,15 & 30000 \\
\hline 5 & $\mathrm{C} 30$ & 30 & 20,00 & 1,90 & 1,25 & 32000 \\
\hline 6 & $\mathrm{C} 35$ & 35 & 23,33 & 2,10 & 1,35 & 33000 \\
\hline 7 & $\mathrm{C} 40$ & 40 & 26,67 & 2,20 & 1,45 & 34000 \\
\hline 8 & $\mathrm{C} 45$ & 45 & 30,00 & 2,30 & 1,55 & 36000 \\
\hline 9 & $\mathrm{C} 50$ & 50 & 33,33 & 2,50 & 1,65 & 37000 \\
\hline
\end{tabular}

The mechanical properties of the reinforcement steel are made in accordance with TS-708 specifications. Table 2 gives the mechanical properties of various reinforcement classes. The mechanical properties of concrete reinforcement steel, S420a, were used in all blocks of reinforced concrete sections in 3 blocks.

Table 2. Mechanical properties of reinforcement steel

\begin{tabular}{|c|c|c|c|c|c|c|}
\hline \multirow{3}{*}{ Mechanical Properties } & \multicolumn{4}{|c|}{ Access Bars } & \multicolumn{2}{|c|}{ Wickerwork } \\
\hline & \multicolumn{3}{|c|}{ Natural Hardness } & \multicolumn{3}{|c|}{ Processed in cold } \\
\hline & S220a & $\mathrm{S} 420 \mathrm{a}$ & S500a & $\mathrm{S} 420 \mathrm{~b}$ & S500bs & S500bk \\
\hline $\begin{array}{l}\text { Minimum yield strength } \\
\text { fyk (MPa) }\end{array}$ & 220 & 420 & 500 & 420 & 500 & 500 \\
\hline $\begin{array}{l}\text { Minimum Copper Strength } \\
\text { FS (MPa) }\end{array}$ & 340 & 500 & 550 & 550 & 550 & 550 \\
\hline $\begin{array}{l}\varnothing \leq 32 \text { Min Break Extension } \\
\Sigma \text { su }(\%)\end{array}$ & 18 & 12 & 12 & 10 & 8 & 5 \\
\hline $\begin{array}{l}32<\emptyset \leq 5 \mathrm{O} \text { Minum } \text { Break } \\
\text { Extension } \\
\Sigma \text { su }(\%)\end{array}$ & 18 & 10 & 10 & 10 & 8 & 5 \\
\hline
\end{tabular}




\section{Load Analysis}

The dead loads of the sections were calculated with the aid of the ETABS program. Figure 1 and Figure 2 show three different models. In addition, we do not need to define dead loads. The other structures of the structure are defined separately as external loads. These loads have been influenced by the structure. As mentioned in TS498, unchanged loads in construction are constant loads. Constant loads also include covering weights together with element weights (Tali beams, main beams, etc.).
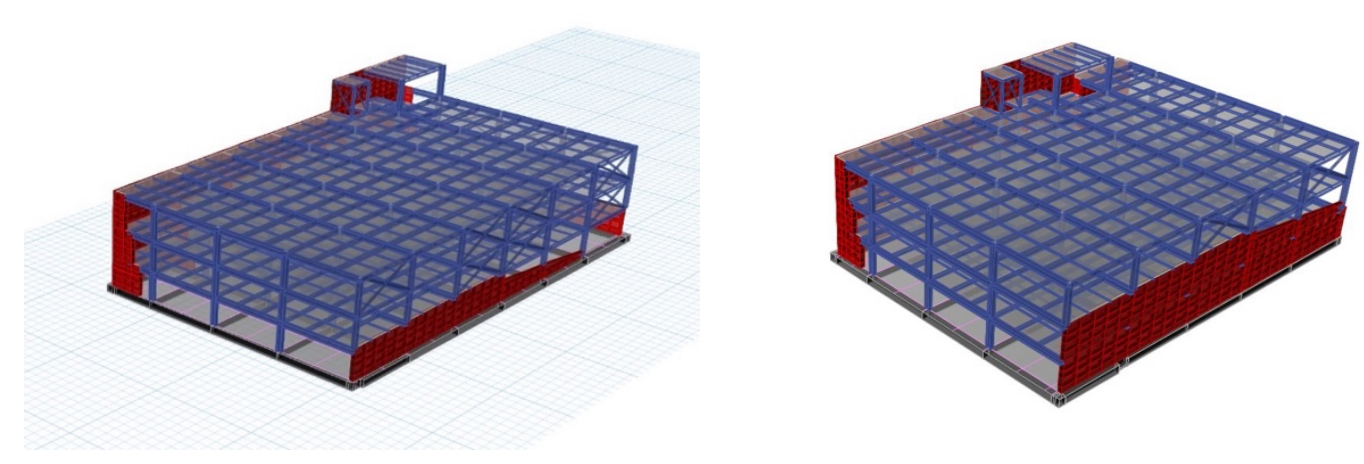

Figure 1 (a) (b) Block perspective view

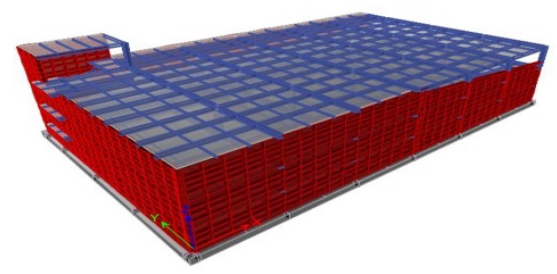

Figure 2 Block perspective view

The fixed loads used in the calculations for all blocks are as follows:

Under all of the floors, under-concrete trapeze sheet will be used. Aldeck 70/915 of the trapezoidal sheet was chosen. The meat thickness will be $1 \mathrm{~mm}$. The unit weight of trapezoidal sheet per square meter is approximately $10.74 \mathrm{~kg} / \mathrm{m}^{2}$. Composite floor weight (for $10 \mathrm{~cm}$ thickness) is approximately $200 \mathrm{~kg} / \mathrm{m}^{2}$ per square meter. All fixed loads of foundation and intermediate floors are designed as approximately $250 \mathrm{~kg} / \mathrm{m}^{2}$ per square meter. On the top floor, the office buildings and other places are different, so the coating, plaster weights, wall weights and so on. adding weights. Calculated by considering $1000 \mathrm{~kg} / \mathrm{m}^{2}$ in square meters. All of these fixed loads were loaded onto the floor in the Etabs program.

For the blocks A, B and C, the load values for the garages are $500 \mathrm{~kg} / \mathrm{m}^{2}$ for the garages, as stated in TS 498 , so that they can all be used as car parks. This load is applied to all floors including foundation.

Wind load was also obtained in the light of meteorological investigations. According to the measurements, the fastest wind intensity is measured to be $102 \mathrm{~km} / \mathrm{h}$. This value is equal to $28.4 \mathrm{~m} / \mathrm{s}$. The value found when $\mathrm{q}$ $=\mathrm{V}_{2} / 1600$ is calculated is $\mathrm{q}=28,22 / 1600=0,497 \mathrm{kN} / \mathrm{m}^{2}$.

Our height is 9.9 meters. The wind load was taken as $0,8 \mathrm{kN} / \mathrm{m}^{2}$ wind load for $9-20 \mathrm{~m}$ height constructions as stated in TS-498. + WINDX, -WINDX, + WINDY, -WINDY wind loads were used and these loads were used in the relevant combinations. Etabsta rod is multiplied by the opening widths of $0,8 \mathrm{kN} / \mathrm{m}^{2}$ and is applied to the elements as wind load. 
In all blocks, the earthquake is designed to be in compliance with the Regulation on Structures to be Performed in Earthquake Regions (2007). Our production consists of three different blocks as they are separated by two dilatations. The earthquake parameters required for each block were made in accordance with earthquake specifications. There are two different earthquake accounts in the model. The first one is "Mod Combination Method" and the second is "Equivalent Earthquake Load Method". All the blocks have both earthquake accounts. The most unfavorable situation is the values formed by equivalent earthquake load method. Therefore, in the calculation of the earthquake which is found by the mode combining method, the coefficients are increased and the calculation of the equivalent earthquake load is reevaluated. Thus, the two accounts reached correct results without contradiction. After these earthquake calculations are made, an automatic earthquake account has been made through the program to be checked separately.

Concrete is the most important load-bearing soil loads. These loads have been applied to curtain elements that take up soil load in the ETABS program.

The topographic slope in the survey area is between 0 and $5 \%$. The investigation area is under the typical climate zone of the Marmara region. The average temperature of the year is 13.7 degrees in Istanbul, the average of January - 5 degrees, the average of July is 22.7 degrees. The maximum number of snowy days is 10 days. The average relative humidity of Istanbul is $76 \%$. The average annual rainfall in Turkey range map shown in Figure 3

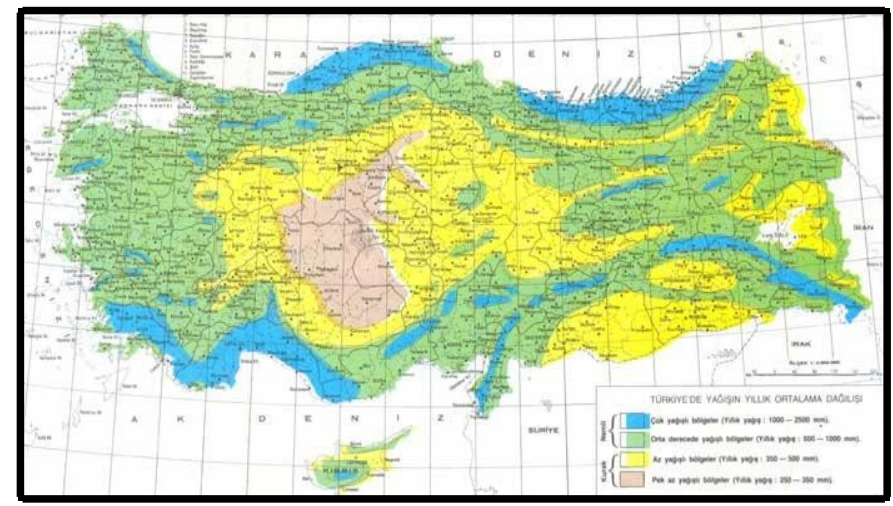

Figure 3. Average annual distribution map of precipitation in Turkey

\section{Review}

The designed structure is a parking structure consisting of 3 basement floors, a floor kattan, and the basic upper elevation is designed as $+8.50 \mathrm{~m}$. Figure 4 shows the layout plan of the building. The final excavation site taking into consideration the base acceptance of the radome of $120 \mathrm{~cm}$ thickness and the extra $40 \mathrm{~cm}$ excavation for drainage and insulation under the foundation; $+6.90 \mathrm{~m}$. There are roads on the other three fronts. Surcharge effects of roads and trams were taken into account in the analysis of the system.

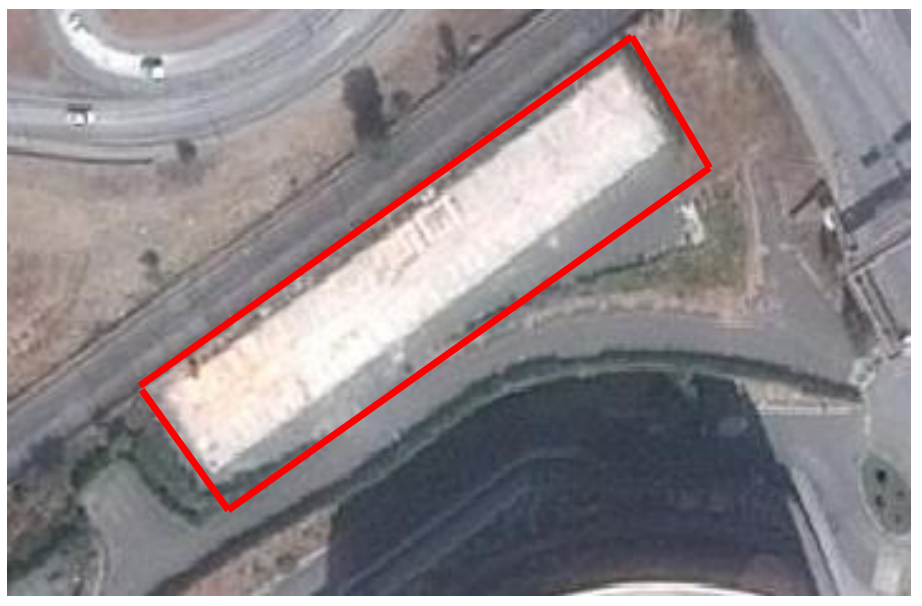


A ground survey report was prepared to determine the mechanical and dynamic parameters of the ground floor and the ground units to be encountered during the excavation and the design parameters were determined in accordance with this report.

\section{Analysis}

In the 1 Masw study carried out in the study area, geophone intervals were taken as $1.0 \mathrm{~m}$ and offset $6.0 \mathrm{~m}$. Assessment of the results obtained at the end of the Masw measurement in the study area, layer structures and related parameters were calculated. As a result of the calculations made from the records, 10 layers were determined. P-S speed log was determined to -20 meters due to adverse reasons such as environmental conditions, opening and power source from the measurement level and Vs30 was calculated and this value was determined as $325 \mathrm{~m} / \mathrm{s}$. Considering the proximity of the investigated area to the active faults, the geological structure and the velocity of Vs30, it is appropriate to take Z3 of the ground group $\mathrm{C}$ of the ground group. The dynamic parameters obtained from Masw 1 and fracture velocities are given in Table 4.

Table 3. Ground Classification according to NEHRP Clauses and Uniform Building Code (UBC)

\begin{tabular}{|c|c|c|}
\hline Ground Class & Definition & Specifications (m / s) \\
\hline A & Rock or Other Similar Formations & $\mathrm{Vs}>800$ \\
\hline B & Very hard sand gravel, very hard killer & $180<\mathrm{Vs}<800$ \\
\hline $\mathrm{C}$ & $\begin{array}{l}\text { Tight to medium tight sand, gravel or } \\
\text { hard clay }\end{array}$ & $180<\mathrm{Vs}<36$ \\
\hline $\mathrm{D}$ & $\begin{array}{l}\text { Cohesionless floor from loose to medium } \\
\text { tight }\end{array}$ & $180>\mathrm{Vs}$ \\
\hline
\end{tabular}

In the Masw measurements, several layers were determined and the values up to an average depth of -20 meters were read and given above under the name Dynamic Parameters.

Table 4. Classification of Cohesive Soils According to Velocity (Özaydın, 1982)

\begin{tabular}{ll}
\hline S Wave Rate $(\mathbf{m} / \mathbf{s e c})$ & Ground Condition \\
\hline$<200$ & Soft - Medium Solid \\
\hline $200-300$ & Solid \\
\hline $300-500$ & Very strict \\
\hline $500-750$ & Hard \\
\hline
\end{tabular}

Table 5. Classification of Cohesionless Soils by Vs Velocity (Özaydın, 1982)

\begin{tabular}{ll}
\hline S Wave Rate $(\mathbf{m} / \mathbf{s e c})$ & Ground Condition \\
\hline$<300$ & Loose \\
\hline $300-600$ & Medium Tight \\
\hline $600-800$ & Tight \\
\hline $800-1000$ & Very Tight \\
\hline
\end{tabular}

It is an indication of the degree of hardness and cementation of the floor. It is important to determine the engineering properties.

$$
E=G\left(\frac{\left.3\left(V_{p}\right) 2-4\left(V_{s}\right) 2\right)}{\left(V_{p}\right) 2-\left(V_{s}\right) 2}\right) \mathrm{kg} / \mathrm{cm}^{2}
$$


Elasticity Module; stiffness of the floor, hardness. 0-1700 kg/ $\mathrm{cm}^{2}$ loose, between $2000-10000 \mathrm{~kg} / \mathrm{cm} 2$ medium strength (dislocated), between $10000-30000 \mathrm{~kg} / \mathrm{cm}^{2}$ strong, and over $30000 \mathrm{~kg} / \mathrm{cm}^{2}$ very strong (Ercan et al., 2001, Özçep 2005, Tezcan et al.)

The floor is a sign of resistance to stiffness and shearing. The shear strength of the soil is defined as the largest shear stress that it can withstand and is an important elastic parameter without estimating the earthquake damage that the ground can cause.

$$
\begin{array}{ll}
\mathrm{G}=(\mathrm{d})(\mathrm{Vs}) 2 / 100 & (\mathrm{~kg} / \mathrm{cm} 2) \\
\mathrm{d}: \text { Density } & \text { Vs : Transverse Wave }
\end{array}
$$

Slip module; determines the resistance of the ground to horizontal forces. The investigations have shown that there are $0-600 \mathrm{~kg} / \mathrm{cm} 2$ loose ground, medium solid ground between $600-3000 \mathrm{~kg} / \mathrm{cm} 2$, solid ground between $3000-10000 \mathrm{~kg} / \mathrm{cm} 2$ and very solid ground above $10000 \mathrm{~kg} / \mathrm{cm} 2$. (Ercan et al., 2001, Özçep 2005, Tezcan et al., 2006).

Vibration is slow in loose places, vibration is rapid in tight and rocky environments. Multi-storey buildings are places where Ivmen are big, and low-rise buildings are affected where there are small ones. Structure weights have a direct effect on ground motion.

Acceleration is large on loose grounds and small in rocky environments. The dominant vibration period $(\mathrm{T})$ is for small undamped vibrations of a soft ground layer on a solid rock layer and is calculated by the following relation.

The upper boundary value of the ground-dominant vibration period is calculated as T: $0.50 \mathrm{sec}$. This value is the value of the field before technical interference. Multi-storey reconstruction is recommended for low-rise buildings where shaking is very sensitive and low-sensitivity for shaking.

\section{Experimental}

Seven direct cutting and two Atterberg experiments were performed on the samples taken from the examination area in the Standard Geotechnical Laboratory.

The index experiments performed in the laboratory environment on the representative samples to determine the physical properties of the soil in the ground environments and the values obtained as a result of this experiment are tabulated below.

Table 6. Index Tests

\begin{tabular}{cccc}
\hline $\begin{array}{c}\text { Drilling } \\
\text { No }\end{array}$ & $\begin{array}{l}\text { Depth } \\
(\mathrm{M})\end{array}$ & $\begin{array}{l}\text { Direct Cutting Experiment } \\
(\mathrm{Kg} / \mathrm{cm} 2)\end{array}$ & $\begin{array}{l}\text { Internal Friction } \\
\text { Angle }(\circ)\end{array}$ \\
\hline SK 1 & 12,0 & 0,652 & 11 \\
\hline SK 2 & 15,0 & 0,831 & 13 \\
\hline SK 3 & 11,0 & 0,714 & 11 \\
\hline SK 4 & 4,50 & 0,771 & 10 \\
\hline SK 5 & 6,0 & 0,447 & 9 \\
\hline SK 5 & 10,0 & 0,742 & 10 \\
\hline SK 6 & 6,0 & 0,654 & 11 \\
\hline SK 7 & 10,50 & 0,904 & 9 \\
\hline SK 8 & 10,0 & 0,546 & \\
\hline
\end{tabular}

Clay units floors; (W3) limestone units are also in the rock class. The clay arabic limestone, clayey silt and less silty clay observed in the study drillings in the study area were determined as the clay arabant in depths between 1.50 and $9.0 \mathrm{~m}$ in SK2 sounding. intermediate decayed limestone units have been identified. In Table 3.14, depth of drilling and TCR, SCR and RQD percentages are given. 
Table 7. Classification of Rocks by Limestone Depth TCR, SCR,RQD \%Values and RQD Values (DEERE,1964).

\begin{tabular}{|c|c|c|c|c|c|}
\hline $\begin{array}{c}\text { Drillig } \\
\quad \text { No }\end{array}$ & $\begin{array}{l}\text { Layer Access } \\
\text { Depth } \\
\text { (M) }\end{array}$ & $\begin{array}{l}\text { TCR } \\
\%\end{array}$ & $\begin{array}{l}\text { SCR } \\
\%\end{array}$ & $\begin{array}{l}\text { RQD } \\
\%\end{array}$ & $\begin{array}{l}\text { Rock } \\
\text { Definition }\end{array}$ \\
\hline \multirow{5}{*}{ SK 2} & $1,50-3,0$ & 8,6 & 0 & 0 & $\begin{array}{c}\text { Very poor } \\
\text { quality }\end{array}$ \\
\hline & $3,0-4,50$ & 44,6 & 44 & 16 & $\begin{array}{c}\text { Very poor } \\
\text { quality }\end{array}$ \\
\hline & $4,50-6,0$ & 16,6 & 10 & 10 & $\begin{array}{c}\text { Very poor } \\
\text { quality }\end{array}$ \\
\hline & $6,0-7,50$ & 18,6 & 6 & 0 & $\begin{array}{c}\text { Very poor } \\
\text { quality }\end{array}$ \\
\hline & $7,50-9,0$ & 0 & 0 & 0 & \\
\hline
\end{tabular}

The excavation works should be controlled in the field of investigation; the metro route and the circumferential roads should be taken gradually against the retaining curb and ground movements. It is necessary to transport the building loads to different floors with homogeneous floors. Since the slopes to be formed during the excavation should not be left open and should be supported with suitable projected retaining structures, it has been decided to build the excavation system.

The designed structure is a parking structure consisting of 3 basement floors, a floor kattan, and the basic upper elevation is designed as $+8.50 \mathrm{~m}$. The final excavation site taking into consideration the base acceptance of the radome of $120 \mathrm{~cm}$ thickness and the extra $40 \mathrm{~cm}$ excavation for drainage and insulation under the foundation; $+6.90 \mathrm{~m}$. This area, which has a non-sloping ground at the site plan review, will form the most critical section of the tramway route. There are roads on the other three fronts. Surcharge effects of roads and trams were taken into account in the analysis of the system.

The ground units to be encountered at the time of excavation according to the information obtained from 8 deep drilling and seismic openings made in the field are listed as follows.

The field and site conditions were examined and four critical sections were identified for the site, and this section was analyzed under the Plexis program, the final elemant program. In the analyzes made, the analyzes were repeated considering the construction steps taking into account the site, ground conditions, groundwater condition and environmental structure effects.

The calculations will be made in the following order;

- Design calculations for each section shall be made with the help of the Plaxis program. In the analysis that takes into account the construction steps, progress will be analyzed until the end of the excavation and attempts will not be made to detect unfavorable conditions.

- It is accepted that the safety system for permanent values of safety index GS $=1.50$ and above is safe.

- The displacement limit in the excavation system will be considered as $0.2 \%$ max and necessary and sufficient elements will be designed to keep the displacements below this level.

- Reinforced concrete design calculations shall be made for the sections that satisfy the safety and displacement criteria.

The required application projects are drawn up and the exquisite application projects are completed. Figure 6 shows the application of the application.

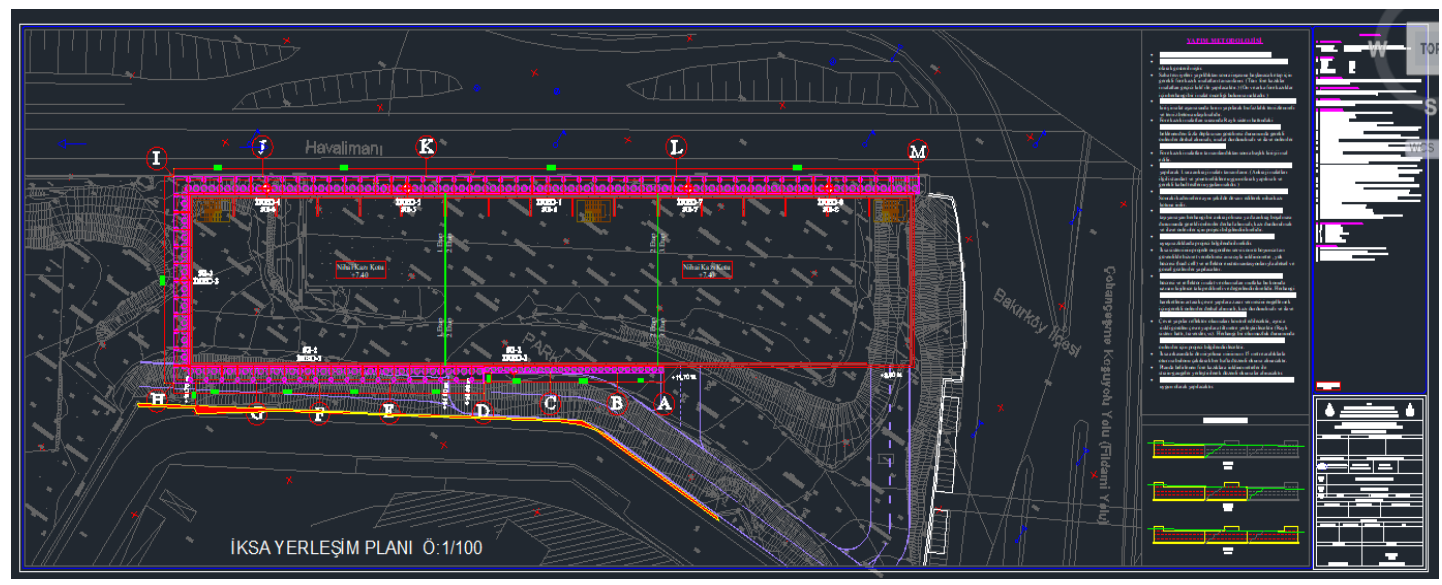

Figure 5. Project implementation 


\section{Conclusion}

In this study, the design criteria of permanent stiffness under repeated loads and the effect of composite steel structure were studied. Structural behavior was investigated under predicted loads. The structure is resized in the light of the existing regulations. Istanbul Borough, Bakırköy District, Osmaniye Mahallesi, 1223 island, 6 Parcels, which is based on the sounding base and basic survey of IBBB - Additional Service Building structure. The thickness, lithological, structural, mechanical and physical properties of the units that make up the structure area, precautions and suggestions to be taken regarding the construction, safe bearing capacity, vertical bearing coefficient, local floor class and foundation based on sounding to determine the floor group are prepared. The structure is composed of normal frames with ductility level in two directions. The cross members are only on the front. Since we have reinforced concrete perforations on the rear facade, steel frames are articulated to the reinforced concrete system.

Within 3 blocks it is reached that it does not constitute any problem. The road, infrastructure and neighboring parcels must be secured before the excavation to be carried out in the investigation area; Progressive measures against ground movements and gradual retaining curves should be taken for subway and perimeter roads. It is necessary to transport the building loads to different floors with homogeneous floors. It can be taken between 0,447 - 0,904 kg / cm2, Ø: 9 - 13 for units of Drawer Formation to be used in fortification calculations.

Our steel car park is 3 storeys and the height of the floors is 3.6 meters, 3.2 meters, 3.1 meters. The steel profiles to be used in the construction are based on the steel grade materials S235 and S275. The IPE and pipe profiler are designed with the S235 steel grade in mind. Made profiler, box profiler, UNP profiler and plates are of steel grade S275. The accessory steel shall be made in accordance with TS 708. Steel profiles are designed according to TS-EN 10025-2 regulation. The total amount of steel used is $1039626.1 \mathrm{~kg}$. Because we have 3 floors, we find the amount of steel coming from a single crack. From here we divide the floor area. The building floor area is 3628.8 square meters. The amount of steel coming from 1 square meter is calculated as $95.49 \mathrm{~kg}$.

Excavation and support systems were determined and applied to the required support structure in terms of ground mechanics and geotechnical engineering evaluations, strength and deformation characteristics of the units encountered during excavation.

In the field it is found that the ground unit is near the filling unit and impervious clay silts. According to the Regulation on Buildings to be Made in Earthquake Regions; the ground group of clayey silt and less silty clay units to be installed in building bases $\mathrm{C}$ - for ground class Z3, Spectrum characteristic periods; TA: 0.15 seconds, TB: 0.60 seconds. The parameters to be taken in disaster work regulation in earthquake areas at 1 st shall be as follows. Effective Ground Acceleration Coefficient (A0): Designed by taking 0.40 .

Static design phase according to the ground values; the soil load from the excavation site and the behavior of the building under permanent loads due to passing by the metro route were investigated. It has been reached as a result that it does not constitute any problem from a static point of view. In the static design phase, the design was carried out taking into consideration the soil loads from the excavation system.

\section{References}

1.Keçeli(1990). Sismik Yöntemlerle Musade Edilebilir Dinamik Zemin Taşıma Kapasitesi Ve Oturmasının Hesaplanması, Jeofizik Cilt 4, Sayı 2/Eylül,

2. C.J.Padfield Phd MA Ceng MICE(1983).Settlement Of Structur On Clay Soils, 1983 PSA Property Service Agency.

3.Deprem Bölgelerinde Yapılacak Yapılar Hakkında Yönetmelik,(2007), Türk Standartları Enstitüsü, Ankara

4. DEREN Ve Diğerleri,(2008). Çelik Yapılar, Istanbul Teknik Üniversitesi,Istanbul

5. Etabs Structural Software For Building Analysis And Desing (2015). Computers Snd Structures Inc. Berkeley,California

6. Ketin, İ., Güner, G.(1989). Mühendislik Jeolojisi Bülteni, Sayı: 1113 - 18 İstanbul.

7. ODABAŞI(1997). Ahşap Ve Çelik Yapı Elemanları, Istanbul

8. ÖZTÜRK,(2002). Çelik Yapılar Kısa Bilgi Ve Problemler,Yıldız Teknik Üniversitesi, Istanbul

9. P.Leonard Capper, W.Fisher Cassie, (1969). İnşaat Mühendisliğinde Zemin Mekaniği.

10.S.GENCOĞLU, E. İNAN, H. GÜLER,(1998). Türkiyenin Deprem Tehlikesi, TMMOB Jeofizik Mühendisleri Odas1.

11. Şekercioğlu, E., (1998). Yapıları Projelendirilmesinde Mühendislik Jeolojisi, Ankara.

12. Tarhan, F., (1989). Mühendislik Jeolojisi, Trabzon.

13. TS498, (1997). Yapı Elemanlarının Boyutlandırılmasında Alınacak Hesap Değerleri , Türk Standartları Enstitüsü, Ankara

14. TS500,(2002)Betonarme Yapıların Tasarım Ve Kuralları

15. TS648, (1980).Çelik Yapıların Hesap Ve Yapım Kuralları, Türk Standartları Enstitüsü, Ankara

16. TS-3357,(1979).Çelik Yapılarda Kaynakıı Birleşimlerin Hesap Ve Yapım Kuralları, Türk Standartları Enstitüsü, Ankara 
17. Ulusay, R., (2001). Uygulamalı Jeoteknik Bilgiler (Genelleştirilmiş 4. Baskı), IMO, Ankara.

18. Ulusay, R., Sönmez, H., (2002). Kaya Kütlelerinin Mühendislik Özellikleri. IMO, Ankara.

19. Uzgider Ve Diğerleri,(2005). IMO-02, Çelik Yapılar, Emniyet Gerilmesi Esasına Göre Hesap Ve Proje Esasları, IMO Istanbul Harbiye Şubesi, Istanbul, Url-1 <Http://Www.Ibb.Gov.Tr>, (2018) 